\title{
Standardize the Selective Mechanization for Enhancing Productivity and Profitability of Rice
}

\author{
S. Ravi* and B. Ramakichenin@Balagandhi \\ Perunthalaivar Kamaraj Krishi Vigyen Kendra, Kurumbapet, Puducherry-605009 India \\ *Corresponding author
}

\begin{tabular}{|l|}
\hline Ke y w or d s \\
Rice, \\
Mechanization, \\
SRI, Yield, \\
Economics \\
\hline Article Info \\
\hline $\begin{array}{l}\text { Accepted: } \\
\text { 16 February } 2018 \\
\text { Available Online: } \\
\text { 10 March } 2018\end{array}$ \\
\hline
\end{tabular}

\section{A B S T R A C T}

Farm Mechanization in rice aims to not only to reduce labour, inputs, human drudgery but also at improving farm productivity. Due to shortage of labour, scarcity of water and energy, the weed competition is going to be the major constraint in achieving higher production in transplanted rice. In order to standardize the selective mechanization for enhancing productivity and profitability of rice, two field experiments were conducted during Kharif 2012 and 2013 at Perunthalaivar Kamaraj Krishi Vigyen Kendra (PKKVK), Puducherry State experimental farm in a Randomized Block Design with three replication and four treatments $\left(\mathrm{T}_{1^{-}}\right.$Mechanical transplanting-15 days old seedlings with SRI principles, $\mathrm{T}_{2^{-}}$Drum seeding with $\mathrm{SRI}$ principles, $\mathrm{T}_{3^{-}}$Normal Transplanting-Best management practice with Flooded system and $\mathrm{T}_{4^{-}}$Farmers practice of the location specific) were taken. Among the various treatments the results revealed that the mechanical transplanting followed by SRI principles with 15 days old seedlings was performed excellent by registering higher grain yield of 6240 and $5630 \mathrm{~kg} \mathrm{ha}^{-1}$ during Kharif 2012 and 2013 respectively. The study of the economics of different treatments of two seasons' results revealed higher net returns and Benefit cost ratio in the Drum seeding with SRI principles followed by Mechanical transplanting followed by SRI principles with 15 days old seedlings

\section{Introduction}

Farm Mechanization in rice aims to not only to reduce labour, inputs, human drudgery but also at improving farm productivity. Due to shortage of labour, scarcity of water and energy, the weed competition is going to be the major constraint in achieving higher production in transplanted rice. The mechanical transplanting followed by SRI principles with 15days old seedlings was performed excellent by registering higher grain yield. Mechanization may be defined as the process of injecting power and machinery between man and materials in a production system. Mechanization as it relates to agriculture requires the study, manufacture, utilization, maintenance and repair of all tools, implements, machines, equipment and structures which will enable the farmer to raise the productivity of human labour economically. Esmay and Hall (1972) defined agricultural mechanization as the science application of mechanical aids for increased production, processing and storage of food 
with less drudgery and increased efficiency.

The demand of cereals by the year 2030 has been projected to reach 43.82 million tons at an anticipated per capita income growth rate of $2 \%$ and 50.62 million tons at an income growth of $3 \%$ (Baqui et al., 2007). This implies that the production of cereals will have to be increased by 2030. Scope for horizontal expansion of cultivable land is limited. To achieve the increased food production target India has to go for vertical expansion of agricultural output over the current situation of its cultivable land. One of the most important means to boost up the vertical expansion of agricultural production is to adopt agricultural mechanization suitable for the Indian farmers. In order to increase the production and cropping intensity further, it has become necessary to mechanize certain farm operations.

The cultivable land is being lost to development work such as road construction, housing, active river damage, etc. To meet food needs, pressures are increasing to grow more food per unit of crop land. Farmers are producing large volumes of crops continuously throughout the year. They are always busy doing many agricultural activities. Most of these operations are accomplished by human labor which is slow, time consuming and costly. Farmers face trouble completing agricultural operations due to labor shortage, especially during the peak planting, harvesting and threshing periods.

Moreover, rural labour force has started to shift from agricultural to industrial sector and service sector, creating an acute agricultural labour shortage during peak planting and harvesting times. In case of occurrences of flood, drought and other natural disasters mechanization is the only option which can handle problems for land preparation, crop establishment, harvesting, threshing and drying of different crops timely. Labor shortage is one of the main constraints to successful crop production. Presently, some farm machineries like weeders, threshers, power tillers, tractors and trailers have been in use in India. Amongst the power-oriented implements, the power tiller holds a notable position. Farm machinery in India needs a special consideration to landholding size and capability of the farmers to buy the machinery. A number of research institutes, Universities and Private Company in the country had invented, imported and also introduced a number of technologies in these fields. The present study was undertaken to find out the scope of mechanization in Puducherry district in south India.

\section{Materials and Methods}

To Standardize the Selective Mechanization for Enhancing Productivity and Profitability of rice, two field experiments were conducted during Kharif 2012 and 2013 at Perunthalaivar Kamaraj Krishi Vigyen Kendra (PKKVK), Puducherry State experimental research farm which is located at Between $11^{\circ} 46^{\prime}$ and $12^{\circ}$ $30^{\prime}$ North latitude, Between $79^{\circ} 36^{\prime}$ and $79^{\circ} 53^{\prime}$ East longitude and at an altitude of $8.85 \mathrm{Mts}$ above mean sea level $5.79 \mathrm{~m}$ above. The rice variety ADT 45 during Kharif 2012. The soil type was clay loam in texture and Acidic in reaction ( $\mathrm{pH}$ 6.9), acidic having electrical conductivity (EC) of $0.22 \mathrm{dSm}^{-1}$ and available $\mathrm{N}, \mathrm{P}, \mathrm{K}$ content were $156.8 \mathrm{~kg} \mathrm{ha}^{-1}, 16.23 \mathrm{~kg}$ $\mathrm{ha}^{-1}$ and $98 \mathrm{~kg} \mathrm{ha}^{-1}$ in Kharif 2012. The rice variety ADT 49 was taken during Kharif 2013. The soil type was clay loam in texture and Acidic in reaction ( $\mathrm{pH}$ 6.0), acidic having electrical conductivity (EC) of $1.38 \mathrm{dSm}^{-1}$ and available N, P, K content were $324.8 \mathrm{~kg} \mathrm{ha}^{-1}$, $14.8 \mathrm{~kg} \mathrm{ha}^{-1}$ and $117 \mathrm{~kg} \mathrm{ha}^{-1}$ in Kharif 2013 with field duration of 105 and 135 days during Kharif 2012 and 2013 respectively, was used in the trial. 
Table.1 Evaluation of SRI and their contribution towards enhancement of grain yield

\begin{tabular}{|c|c|c|c|}
\hline \multicolumn{2}{|r|}{ Treatment } & \multirow{2}{*}{$\begin{array}{c}\text { Kharif } 2012 \\
\text { Grain Yield } \\
\text { (t/ha) } \\
6.24\end{array}$} & \multirow{2}{*}{$\begin{array}{c}\text { Kharif } 2013 \\
\text { Grain } \\
\text { Yield (t/ha) } \\
5.63\end{array}$} \\
\hline $\mathrm{T} 1$ & $\begin{array}{l}\text { SMSRI - ( } 15 \text { day old seedling mat nursery use of transplanter } \\
\text { for planting and followed by SRI principles of crop management) }\end{array}$ & & \\
\hline $\mathrm{T} 2$ & Drum seeding followed by SRI principles & 5.77 & 4.86 \\
\hline $\mathrm{T} 3$ & $\begin{array}{l}\text { Normal transplanting - Best management practices } \\
\text { (Flooded rice system) }\end{array}$ & 6.11 & 5.36 \\
\hline \multirow[t]{3}{*}{$\mathrm{T} 4$} & Farmers practice of the location & 5.08 & 4.41 \\
\hline & $\mathrm{CD}(\mathbf{0 . 0 5})$ & 0.65 & 0.49 \\
\hline & C.V. $(\%)$ & 5.60 & 4.87 \\
\hline
\end{tabular}

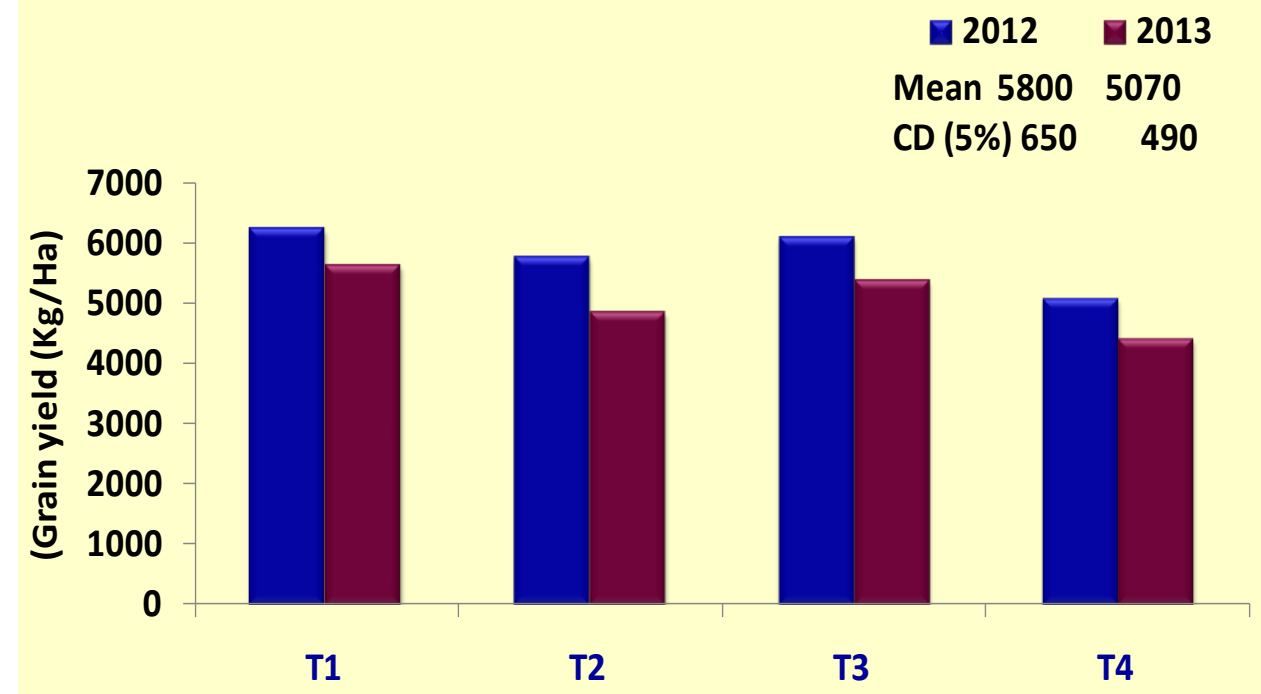

Table.2 Evaluation of SRI and their contribution towards enhancement of panicle number $\left(\mathrm{m}^{2}\right)$

\begin{tabular}{|c|c|c|c|}
\hline \multicolumn{2}{|c|}{ Treatment } & \multirow{2}{*}{$\begin{array}{c}\text { Kharif } \\
\mathbf{2 0 1 2} \\
\text { panicle } \\
\text { number } \\
/ \mathbf{~ m}^{\mathbf{2}} \\
492\end{array}$} & \multirow{2}{*}{$\begin{array}{c}\text { Kharif } \\
\mathbf{2 0 1 3} \\
\text { panicle } \\
\text { number } \\
/ \mathbf{m}^{2} \\
465\end{array}$} \\
\hline $\mathrm{T} 1$ & $\begin{array}{l}\text { SMSRI - ( } 15 \text { day old seedling mat nursery use of transplanter } \\
\text { for planting and followed by SRI principles of crop management) }\end{array}$ & & \\
\hline $\mathrm{T} 2$ & Drum seeding followed by SRI principles & 226 & 385 \\
\hline T3 & $\begin{array}{l}\text { Normal transplanting - Best management practices } \\
\text { (Flooded rice system) }\end{array}$ & 483 & 430 \\
\hline \multirow[t]{3}{*}{$\mathrm{T} 4$} & Farmers practice of the location & 398 & 364 \\
\hline & CD (0.05) & 102 & 35.59 \\
\hline & C.V. $(\%)$ & 11.37 & 4.33 \\
\hline
\end{tabular}




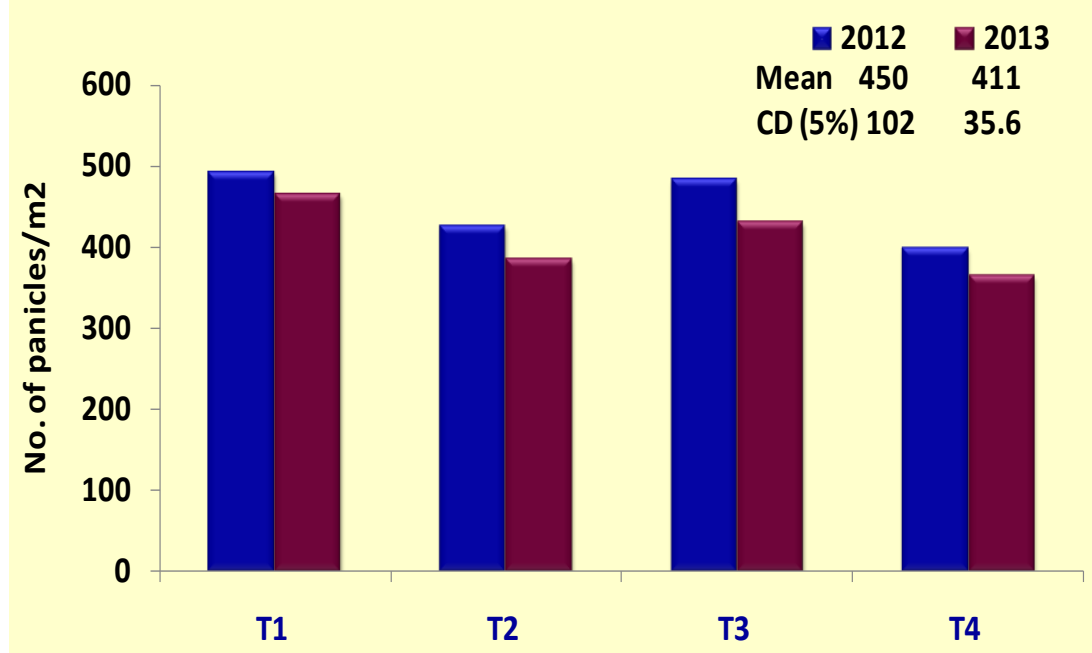

Table.3 Evaluation of SRI and their contribution towards enhancement of panicle weight (g)

\begin{tabular}{|c|c|c|c|}
\hline \multicolumn{2}{|c|}{ Treatment } & \multirow{2}{*}{$\begin{array}{c}\begin{array}{c}\text { Kharif } \\
2012\end{array} \\
\text { panicle } \\
\text { weight (g) }\end{array}$} & \multirow{2}{*}{$\begin{array}{c}\text { Kharif } \\
2013 \\
\text { panicle } \\
\text { weight } \\
\text { (g) } \\
3.11\end{array}$} \\
\hline $\mathrm{T} 1$ & $\begin{array}{l}\text { SMSRI - (15 day old seedling mat nursery use of transplanter } \\
\text { for planting and followed by SRI principles of crop management) }\end{array}$ & & \\
\hline $\mathrm{T} 2$ & Drum seeding followed by SRI principles & 2.50 & 2.60 \\
\hline T3 & $\begin{array}{l}\text { Normal transplanting - Best management practices } \\
\text { (Flooded rice system) }\end{array}$ & 2.70 & 2.93 \\
\hline \multirow[t]{3}{*}{ T4 } & Farmers practice of the location & 2.47 & 2.50 \\
\hline & $\mathrm{CD}(\mathbf{0 . 0 5})$ & 0.73 & 0.41 \\
\hline & C.V.(\%) & 13.72 & 7.36 \\
\hline
\end{tabular}

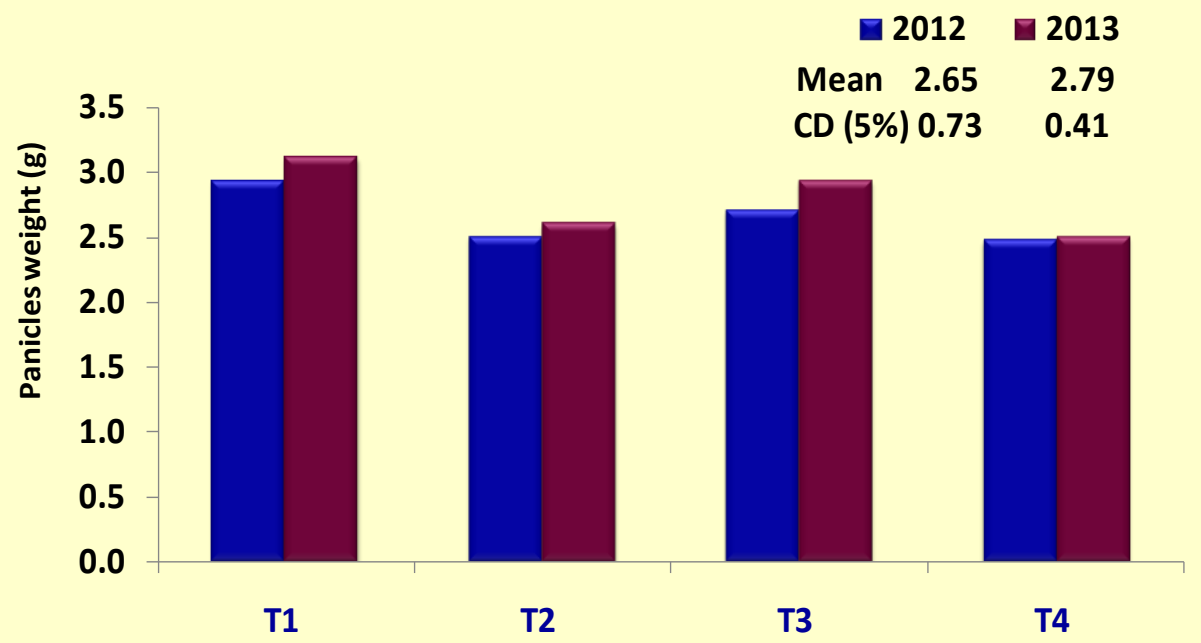




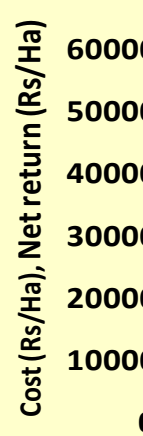

G Cost 2012 Cost 2013 N 2012 N 2013

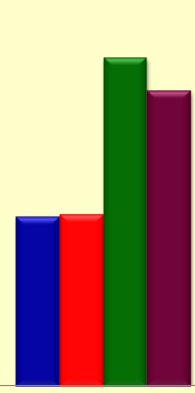

T1

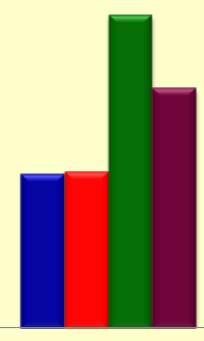

T2

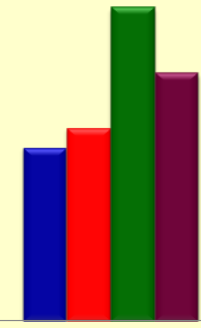

T3

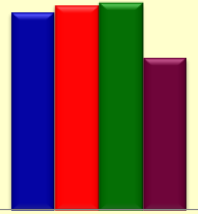

T4

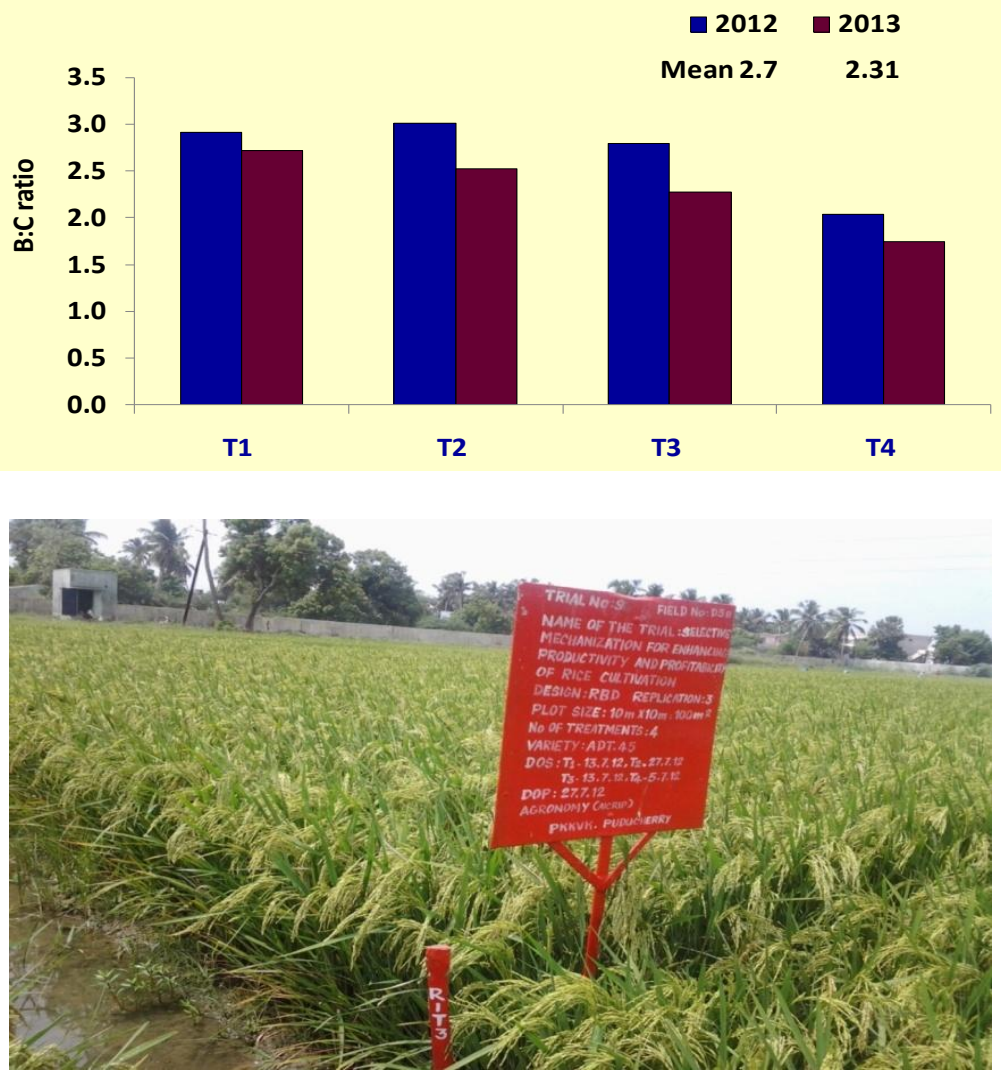

\section{Agronomic practices under SMSRI and Drum Seeding}

\begin{tabular}{|l|l|}
\hline SMSRI / Transplanter & Drum seeding cum SRI \\
\hline Tray Nursery & Direct Sowing \\
\hline $15 \mathrm{~kg}$ Seeds & $30 \mathrm{~kg}$ Seeds \\
\hline Planting through Tranplanter & Sowing through Drum seeder \\
\hline $1-2$ seedlings / hill & $3-4$ seedlings / hill \\
\hline $12-15$ days old seedlings & - \\
\hline Wider spacing 30 21 (SMSRI) & $25 \mathrm{~cm}$ (DS) only row to row \\
\hline
\end{tabular}

\begin{tabular}{|l|l|}
\hline \multicolumn{2}{|l|}{ Agronomic practices under BMP and Framers practices } \\
\hline Best Management practices & Framers practices \\
\hline Tray Nursery & Raised bed \\
\hline Planting through SRI & Planting through women labour \\
\hline $1-2$ seedlings $/$ hill & $3-4$ seedlings / hill \\
\hline $12-15$ days old seedlings & 25 days old seedlings \\
\hline Wider spacing $25 \times 25 \mathrm{~cm}$ & Recommended spacing $20 \times 10 \mathrm{~cm}$ \\
\hline Weeding through cono weeder & Weeding through women labour \\
\hline Fertilizer application -4 splits & Fertilizer application -3 splits \\
\hline
\end{tabular}




\section{Treatment Details for RBD}

\section{T1 SMSRI - (15 day old seedling mat nursery use of transplanter for plantingand followed by SRI principles of crop management) \\ T2 Drum seeding followed by SRI principles \\ T3 Normal transplanting - Best management practices (Flooded rice system) \\ T4 Farmers practice of the location}

The selected packages of treatment details are as follows: $\mathrm{T}_{1}$ - Mechanical transplanting-15 days old seedlings with SRI principles, $\mathrm{T}_{2-}$ Drum seeding with SRI principles, $\mathrm{T}_{3}$ Normal Transplanting-Best management practice with Flooded system and $\mathrm{T}_{4}$ - Farmers practice of the location specific) were taken. Experiment was laid out in a Randomized Block Design with three replication.

\section{Results and Discussion}

Transplanting is a labour intensive operation along with time consuming and health issues related to it. Further from our study we could easily evaluate that high skill is necessary for the operation so as to achieve uniform number of seedlings per hill, spacing between hill to hill and as well as between the rows. It is well known fact that the time available between the harvest of one crop and transplanting of paddy is short.

Hence the maximum yield can only be through timely transplanting according to the sessional approach. So it could be said that maximum yield is a function of date of transplanting. These are few factors that basically emphasis the need for a suitable mechanical transplanter in India which suits the small scale labours and moreover which are easy to handle and maintain. Japanese transplanters are hugely successful worldwide.

In this study, to standardize the Mechanical transplanting followed by SRI principles with
15 days old seedlings performed better by registering higher grain yield of 6240 and $5630 \mathrm{~kg} \mathrm{ha}^{-1}$ during Kharif 2012 and 2013 respectively. Higher net returns were observed in Mechanical transplanting. Mechanical transplanting followed by SRI principles with 15 days old seedlings may be recommended to the farmers based on its cost effectiveness and ecological friendliness. The out cum of the results was nearly $90-95 \%$ of our state paddy farmers adopting Mechanical transplanting (Table 1-3).

In this study it was concluded that high labour demand during the peak periods adversely affects the time lines of operation, thereby reducing the crop yield. To offset these problems, mechanical transplanting is the solution.

Mechanization not only changes the structure of labour in agriculture, but also influences the nature of the workload. Hence there is a need of mechanization in rice cultivation sector. In this direction Rice transplanter helps us to see bright future ahead Existing models of rice transplanters are highly efficient and effective in term of cultivation of rice in paddy field.

\section{Acknowledgement}

Indian Institute of Rice Research (IIRR), Hyderabad and Travel grant received from the Centre for International Co-operation in Science (CICS), Chennai, India is gratefully acknowledged 


\section{References}

Bala Ibrahim and Wan Ishak Wan Ismail (2014), Development of System Rice Intensification (SRI) Paddy Transplanter, Asian Journal of Agricultural Sciences, 6(2), 48-53.

Baldev Raj Kamboj, Dharam Bir Yadav, AshokYadav, Narender Kumar Goel, Gurjeet Gill, Ram K. Malik, Bhagirath Singh Chauhan (2013), Mechanized Transplanting of Rice (Oryza sativa L.) in Non-puddled and No-Till Conditions in the Rice-Wheat Cropping System in Haryana, India, American Journal of Plant Sciences, 2013, 4, 2409-2413

Goel A.K, D. Behera and S. Swain (2008), Effect of Sedimentation Period on Performance of Rice Transplanter, Agricultural Engineering International: the CIGR Ejournal, Vol. X., Manuscript PM 07034.

Pradhan. S and S.K. Mohanty (2014), ErgoEconomical Analysis of Different
Paddy Transplanting Operations in Eastern India, IOSR Journal of Agriculture and Veterinary Science, Volume 6, 23-2

Rajvir Yadav, Mital Patel, S.P. Shukla and S. Pund (2007), Ergonomic evaluation of manually operatedsix-row paddy transplanter, International Agricultural Engineering Journal, 16(3-4), 147-157.

Rampuram Jayapalreddy and Dr. N. Sandhya Shenoy (2013), a comparative economic analysis of Traditional and System of Rice Intensification (SRI) Rice Cultivation practices in Mahabubnagar district of Andhra Pradesh, International Journal of Scientific and Research Publications, Volume 3, ISSN 22503153.

Singh. G, T. R. Sharma, C.W. Bockhop (1985), Field Performance Evaluation of a Manual Rice Transplanter, Journal of agricultural Engineering Research, 32,259-268.

\section{How to cite this article:}

Ravi, S. and Ramakichenin@Balagandhi, B. 2018. Standardize the Selective Mechanization for Enhancing Productivity and Profitability of Rice. Int.J.Curr.Microbiol.App.Sci. 7(03): 18201826. doi: https://doi.org/10.20546/ijcmas.2018.703.214 